\section{'Daraprim' Resistance in Experimental Malarial Infections}

'DARAPrIM' [2 : 4-diamino-5-(-4'-chlorophenyl)-6ethyl pyrimidine (50-63) $]$ has been described ${ }^{1}$ as having high antimalarial activity in laboratory infections of Plasmodium gallinaceum, Plasmodium berghei and Plasmodium cynomolgi. More recently, it has also been tried in the treatment and suppression of human malaria ${ }^{2}$. It has been shown that proguanil-resistant strains of the first two species are sensitive to 'Daraprim' and that 'Daraprim' resistance is not easily produced in $P$. gallinaceum infections ${ }^{3}$.

Since the publication of these experiments, further work has resulted in the production of two strains highly resistant to 'Daraprim' : the first, a strain of $P$. gallinaceum in young chicks, and the second, a strain of $P$. berghei in white mice. The $P$. gallinaceum resistant-strain has been previously reported ${ }^{3}$ as having only a very slight degree of resistance after fourteen successive passages treated with approximately the minimum effective dose of the drug. Further similar treatment with increasing doses when the previous dose-level proved ineffective has resulted, after forty-two treated passages within a total period of seventy weeks, in a considerable degree of resistance to the drug. The method of infecting and dosing the chicks is similar to that previously described ${ }^{1}$.

Using a somewhat different method, a highly resistant strain of $P$. berghei was produced in a much shorter time. 'The technique, in brief, was to administer to an infected mouse a single dose of the drug when examination of a stained blood film showed 40-50 per cent of the red blood cells to be parasitized; on subsequent relapse after recession of the parasitæmia, the mouse was dosed for a second time and on relapse the strain was passaged. After two further successive mice had received a single dose each in this way, the strain was tested along with the normal untreated parent strain and proved to be more than twenty times less sensitive to the action of 'Daraprim'. Treatment with one more single dose and three drug courses carried out as described by Goodwin 4 has resulted in a very high degree of drug resistance.

'The results of some assays of 'Daraprim' on the parent and treated strains of $P$. gallinaceum and $P$. berghei are shown in the accompanying table.

'DARAPRIM' ASSAYS ON NORMaI aND TREATED Strains of $P$, gallinaceum AND $P$. berghei

\begin{tabular}{|c|c|c|c|c|}
\hline Exp. & Species & Strain & $\begin{array}{c}\text { Minimum effect- } \\
\text { ive dose* of } \\
\text { 'Daraprim' } \\
\text { (mgm./kgm.) }\end{array}$ & $\begin{array}{c}\text { Degree of } \\
\text { resistance* }\end{array}$ \\
\hline $1+$ & $P$. gallinaceum & $\begin{array}{c}\text { Parent } \\
\text { Untreated } \\
\text { Treated }\end{array}$ & $\begin{array}{l}0.03 \\
3 \cdot 8\end{array}$ & 127 \\
\hline 2 & P. berghei & $\begin{array}{c}\text { Parent } \\
\text { Untreated } \\
\text { Treated }\end{array}$ & $\begin{array}{c}0.04 \\
>0.8\end{array}$ & $>20$ \\
\hline 3 & $\begin{array}{c}\text { Parent } \\
\text { Untreated } \\
\text { Treated }\end{array}$ & 13 & 325 \\
\hline
\end{tabular}

* As previousiy defined (ref. 3).

$\dagger$ Exp. 1. After forty-two treated passages. Exp. 2. After four
. And three drug courses.

Thus it is seen that 'Daraprim' resistance may arise quite quickly, particularly if the drug is called upon to act on a large population of parasites, as in the development of the resistant strain of $P$. berghei. Where, however, the drug is made to act more as a suppressant, as in the technique used for the develop- ment of the resistant strain of $P$. gallinaceum, the initial development of resistance is slow and prolonged.

In human malaria the main use of 'Daraprim' will probably be as a suppressant. As in the case of proguanil, where resistance can easily be induced in the laboratory, the problem of 'Daraprim' resistance in the field is unlikely to become a serious disadvantage to its use.

Full details of these and further observations will be published elsewhere.

Wellcome Laboratories of Tropical Medicine,

\section{M. ROLLO}

Euston Road,

London, N.W.1.

$$
\text { April } 10 .
$$

${ }^{2}$ Falco, E. A., Goodwin, I. G., Hitchings, G. H., Rollo, I. M., and Russell, P. B., Brit. J. Pharmacol., 6, 185 "(1951).

${ }^{2}$ Archibald, H. M., Brit. Med. J., 2, 821 (1951). McGregor, I. A., and Smith, D. A., Brit. Med.' Brit. Med. J., 1, 732 (1952).

3 Rollo, I. M., Nature, 168, 332 (1951).

4 Goodwin, I. G., Nature, 164, 1133 (1949).

\section{Detection of Digitalis Glycosides on Paper Chromatograms}

Neher and Wettstein ${ }^{1}$ have used a solution of antimony trichloride in organic solvent to identify certain steroids on paper chromatograms. Although Jaminet ${ }^{2}$ has used an acetic anhydride solution of antimony trichloride for the spectrophotometric identification of cardiac glycosides, he has not reported its use with paper chromatograms. Work in this laboratory has shown that antimony trichloride may be successfully applied to this field.

Reagents at present in use for the detection of cardiac glycosides on paper suffer from several disadvantages: the colour produced by m-dinitrobenzene is transient and does not distinguish individual glycosides, hydrochloric acid vapour destroys the paper, while with trichloracetic acid the intense fluorescence produced by traces of gitoxigenin completely masks that of other less reactive glycosides. The antimony trichloride in chloroform (CarrPrice reagent) reported here reacts with less than $0.5 \mu \mathrm{gm} . / \mathrm{cm} .{ }^{2}$ of glycoside, giving permanent and distinctive colours in visible and ultra-violet light. while the background remains unaffected. Moreover, if stored in an amber-coloured bottle, the reagent keeps indefinitely.

For the chromatographic development, the glycoside solution was applied to the starting line with an 'Agla' micrometer pipette in a spot not more than $0.5 \mathrm{~cm}$. in diameter. The chromatogram was then developed until the solvent front had run $30 \mathrm{~cm}$. (During development the 'spot' had spread until it

\begin{tabular}{|c|c|c|c|c|}
\hline \multirow{2}{*}{ Glycoside } & \multicolumn{2}{|c|}{ Visible light } & \multicolumn{2}{|c|}{ Ultra-violet light } \\
\hline & Colour & Sensitivity & Colour & Sensitivity \\
\hline Digitoxin & $\begin{array}{l}\text { Red-mauve, } \\
\text { changing to } \\
\text { blue-grey }\end{array}$ & $0.75 \mu \mathrm{gm}$ & Red & $0.25 \mu \mathrm{gm}$. \\
\hline Gitoxin & $\begin{array}{l}\text { Mauve, } \\
\text { changing to } \\
\text { grey }\end{array}$ & $0.75 \mu \mathrm{gm}$. & $\underset{\text { green }}{\text { Apple- }}$ & $0.25 \mu \mathrm{gm}$. \\
\hline Digitoxigenin & $\begin{array}{l}\text { Pale tur- } \\
\text { quoise-blue }\end{array}$ & $1.0 \% \mathrm{gm}$. & Negative & - \\
\hline Gitoxigenin & $\begin{array}{l}\text { Bright } \\
\text { orange- } \\
\text { yellow }\end{array}$ & $0.75 \mu \mathrm{gm}$. & $\begin{array}{l}\text { Bright } \\
\text { orange }\end{array}$ & $0.25 \mu \mathrm{gm}$. \\
\hline
\end{tabular}

